ISSN 1392-3196 / e-ISSN 2335-8947

Zemdirbyste-Agriculture, vol. 105, No. 1 (2018), p. 39-48

DOI 10.13080/z-a.2018.105.006

\title{
Genetic parameters of Triticum aestivum and Triticum durum for technological quality properties in Serbia
}

\author{
Gordana BRANKOVIĆ ${ }^{1}$, Dejan DODIG ${ }^{2}$, Vesna PAJIĆ ${ }^{1}$, Vesna KANDIĆ ${ }^{2}$, \\ Desimir KNEŽEVIĆ ${ }^{3}$, Nenad ĐURIĆ ${ }^{4}$, Tomislav ŽIVANOVIĆ ${ }^{1}$ \\ ${ }^{1}$ University of Belgrade \\ Nemanjina 6, 11000 Belgrade, Serbia \\ E-mail: gbrankovic@agrif.bg.ac.rs \\ ${ }^{2}$ Maize Research Institute "Zemun Polje" \\ Slobodana Bajića 1, 11185 Belgrade-Zemun Polje, Serbia \\ ${ }^{3}$ University of Priština \\ Jelene Anžujske bb, 38228 Zubin Potok, Serbia \\ ${ }^{4}$ John Naisbitt University \\ Maršala Tita 39, 24300 Bačka Topola, Serbia
}

\begin{abstract}
Proteins are important in determining the nutritional value of wheat, and among them gluten determines the baking quality of bread wheat and pasta-making technological properties of wheat. By assessing genetic parameters of wheat quality traits, it is possible to elucidate potential for improvement. The plant material consisted of 30 genotypes of bread and durum wheat of worldwide origin. The trials were sown at three locations in Serbia during two vegetation seasons 2010-2011 and 2011-2012. Protein content, wet gluten content, Zeleny sedimentation volume and deformation energy were determined by near infrared spectrometry. The objectives of this investigation were to assess: i) variability, components of variance, heritability in a broad sense $\left(\mathrm{h}_{\mathrm{b}}^{2}\right)$, expected genetic advance for protein content, wet gluten content, Zeleny sedimentation volume and deformation energy; ii) associations between agronomic characteristics and protein content, wet gluten content, Zeleny sedimentation volume and deformation energy in order to determine indirect selection feasibility. In durum wheat, the highest coefficients of genetic and phenotypic variation $\left(\mathrm{CV}_{\mathrm{g}}\right.$ and $\left.\mathrm{CV}_{\mathrm{ph}}\right)$ were recorded for deformation energy in bread wheat $(18 \%$ and $18.4 \%$, respectively), whereas the lowest values of $4.1 \%$ and $4.6 \%$ were shown for protein content. The relation genetic component of variance $\left(\sigma_{\mathrm{g}}^{2}\right)$ / component of variance due to genotype $\times$ environment interaction $\left(\sigma_{\mathrm{ge}}^{2}\right)>1$ was observed for protein content (3.2), wet gluten content (2.9) and deformation energy (3.9), and equal to one for Zeleny sedimentation volume, in bread wheat. In durum wheat, $\sigma_{\mathrm{ge}}^{2} / \sigma_{\mathrm{g}}^{2}>1$ was detected for protein content (1.4), wet gluten content (1.5), Zeleny sedimentation volume (2.1) and deformation energy (1.4). Considering very high and high $\mathrm{h}_{\mathrm{b}}^{2}$ observed for deformation energy and Zeleny sedimentation volume $(95.8 \%$ and $86.2 \%$, respectively) in bread wheat, coupled with high genetic advance (36.3\% and $28.1 \%$, respectively), success from classical breeding can be anticipated. Grain thickness was strongly associated with Zeleny sedimentation volume, and to a lesser extent with protein content, wet gluten content and deformation energy in bread and durum wheat, and along with grain vitreousness in durum wheat, can serve for indirect selection.
\end{abstract}

Key words: common wheat and durum wheat, expected genetic advance, gluten strength, proteins, wet gluten, Zeleny sedimentation volume.

\section{Introduction}

The major wheat species covering $95 \%$ of world wheat production is a hexaploid Triticum aestivum L., known as "common" or "bread" wheat, being adapted to a wide range of moisture conditions from xerophytic to littoral (Monneveux et al., 2012). At the second place regarding total wheat world production of 35-40 millions of tonnes is tetraploid species Triticum durum Desf., being adapted to the hot, dry conditions surrounding the Mediterranean Sea, and similar climates in other regions (Shewry, Hey, 2015). The flour from common wheat is used for making bread, cookies and pastries, whereas semolina and flour from durum wheat is used for pasta, couscous, leavened and unleavened bread, bulgur and freekeh.

Please use the following format when citing the article:

Branković G., Dodig D., Pajić V., Kandić V., Knežević D., Đurić N., Živanović T. 2018. Genetic parameters of bread wheat and durum wheat genotypes for technological quality properties in Serbia. Zemdirbyste-Agriculture, 105 (1): 39-48 DOI 10.13080/z-a.2018.105.006 
Protein content represents an important factor for price determination in wheat trading, commanding higher prices of higher protein hard wheat, and of lower protein soft wheat (Carver, 2009). Improving quality is one of the most important goals of durum wheat breeding programs in the European Union (EU), with premiums to boost the cultivation of high-quality cultivars (Royo, Briceño-Félix, 2011). The EU durum wheat quality index increased by $6.25 \%$ by decreasing protein content by $\sim 10 \%$, but by increasing protein per ha at a rate of $0.35 \%$ year ${ }^{-1}$, and also by increasing gluten strength by 27.9 $32.1 \%$ year $^{-1}$ (Subira et al., 2014). Protein content of 12.600 genotypes in the USDA World Wheat Collection ranged from $7 \%$ to $22 \%$ of the dry weight, but the majority of the genotypes had $10-15 \%$ of the dry weight (Shewry, Hey, 2015). Protein content is a typical quantitative trait controlled by complex genetic arrangements under high influence of environmental factors.

Gluten has a key role in determining the unique baking quality of wheat by conferring water absorption capacity, cohesiveness, viscosity and elasticity on dough (Wieser, 2007). The gluten proteins consist of glutenins and gliadins as the most important wheat storage proteins, representing $75-85 \%$ of the total grain proteins, exhibiting richness in asparagine, glutamine, arginine, proline, and scarcity of lysine, tryptophan and methionine (Žilić et al., 2011). Genetic effects are generally considered to be the most significant for qualitative characteristics of gluten. Wet gluten is correlated with protein content and represents common flour specification required by end-users in the food industry. The Zeleny sedimentation volume test is based on the ability of the endosperm storage proteins to swell and flocculate in a lactic acid solution, showing positive correlations with gluten strength and breadmaking quality, but also with the cooking quality of pasta and with bread-loaf volume (Deng et al., 2013). Both higher gluten content and a better gluten quality give rise to slower sedimentation, and ultimately higher Zeleny test values.

The wheat dough rheological properties are essential in bread-making technology, by controlling dough mechanical handling, proofing and baking, influencing the quality of the bakery products (Gaines et al., 2006). One of the most relevant dough rheological properties is the deformation energy or dough strength, predicting flour processing behaviour and sufficient firmness of wellcooked semolina products (Vizitiu et al., 2012).

The objectives of this research were to explore the variability and estimate components of variance, heritability in a broad sense, and expected genetic advance for protein, wet gluten, Zeleny sedimentation volume and deformation energy in bread and durum wheat genotypes from the multi-environment trial in Serbia. The genotype by trait analysis was used for determination of the associations of agronomic traits with these four technological quality properties in order to perceive the notion of the indirect selection.

\section{Materials and methods}

Plant material, experimental design and field trials. The genetic material grown in a multi-environment trial comprised 15 bread wheat (Triticum aestivum L. ssp. aestivum) and 15 durum wheat (Triticum durum Desf.) genotypes from the GeneBank of the Institute of Field and Vegetable Crops in Novi Sad and from the GeneBank of the Maize Research Institute "Zemun Polje" in Belgrade, both in Serbia. The names, codes and countries of origin of bread wheat genotypes are: 'Žitarka' (P1), Croatia, 'Stephens' (P2), USA, 'Renan' (P3), France, 'Caldwell' (P4), USA, 'Abe' (P5), USA, 'Auburn' (P6), USA, 'Frankenmuth' (P7), USA, 'Apache' (P8), France, ZP AU 12 (P9), Macedonia, 'Marija' (P10), Croatia, 87/Ip (P11), Serbia, 'Tecumseh' (P12), USA, 'Pobeda' (P13), Serbia, 'Zemunska rosa' (P14), Serbia and 'Ludwig' (P15), Austria. The names, codes and countries of origin of durum wheat genotypes are: 37EDUYT No. 7922 (D1), Mexico, 37EDUYT No. 7896 (D2), Mexico, 37EDUYT No. 7817 (D3), Mexico, 'Varano' (D4), Italy, 37EDUYT No. 7821 (D5), Mexico, 37EDUYT No. 7880 (D6), Mexico, 10/I (D7), Serbia, SOD 55 (D8), Slovakia, 37EDUYT /07 No. 7803 (D9), Mexico, DSP-MD-01 No. 66 (D10), Syria, 34/I (D11), Serbia, 37EDUYT No. 7820 (D12), Mexico, 37EDUYT /07 No. 7857 (D13), Mexico, 37EDUYT /07 No. 7849 (D14), Mexico and 120/I (D15), Serbia. The durum wheat genotypes from Mexico belong to CIMMYT-International Maize and Wheat Improvement Centre from 37EDUYT-37 ${ }^{\text {th }}$ Elite Durum Unreplicated Yield Trial, and a durum wheat genotype from Syria belong to ICARDA-International Centre for Agricultural Research in the Dry Areas from DSP-MD-01-Durum Segregating PopulationsMediterranean Dryland (season 2000-2001).

The locations of field trials were: 1) Rimski Šančevi (RS) $\left(45^{\circ} 19^{\prime} 51^{\prime \prime} \mathrm{N}, 19^{\circ} 50^{\prime} 59^{\prime \prime} \mathrm{E}\right)$ within the Institute of Field and Vegetable Crops, 2) Zemun Polje (ZP) $\left(44^{\circ} 52^{\prime} \mathrm{N}, 20^{\circ} 19^{\prime}\right.$ E) within Maize Research Institute "Zemun Polje" and 3) Padinska Skela (PS) (445ㄱ' N, 20²6' E) within PKB-Agricultural Corporation Belgrade, Agroeconomik Institute; all three in Serbia. The investigation was conducted during two vegetation seasons 2010-2011 ( $1^{\text {st }}$ year) and 2011-2012 ( $2^{\text {nd }}$ year). Field experiments were laid out in a randomized complete block design with four replications. The experimental plot consisted of 5 rows of $1 \mathrm{~m}$ in length with the interrow spacing of $20 \mathrm{~cm}$. The elementary plot consisted of three inner rows of $0.6 \mathrm{~m}^{2}(3 \times 0.2 \times 1 \mathrm{~m})$, and seeds from elementary plot were used for the analyses. According to WRB (2014), Haplic Chernozem (CHha) soil is at the RS and ZP locations, whereas Humic Gleysol (GLhu) is at the PS. The rates of fertilizers were determined based on the soil chemical characteristics and available amounts of phosphorus $(\mathrm{P})$, potassium $(\mathrm{K})$ and nitrogen $(\mathrm{N})$ in the soil. A total of $45 \mathrm{~kg} \mathrm{ha}^{-1} \mathrm{~N}, 45 \mathrm{~kg} \mathrm{ha}^{-1} \mathrm{P}$ and $45 \mathrm{~kg} \mathrm{ha}^{-1} \mathrm{~K}$ were applied in PS1 and PS2 environments, while $18 \mathrm{~kg} \mathrm{ha}^{-1}$ $\mathrm{N}$ and $78 \mathrm{~kg} \mathrm{ha}^{-1} \mathrm{P}$ were applied prior to sowing in the ZP1, ZP2, RS1 and RS2 environments. Sowing in both seasons was done by hand at RS location in mid-October, and by hand at PS and ZP locations, in late October, and early November, respectively. The top dressing was employed in March and April with the application of 46 $\mathrm{kg} \mathrm{ha}^{-1} \mathrm{~N}$ in PS1 and PS2 environments, $92 \mathrm{~kg} \mathrm{ha}^{-1} \mathrm{~N}$ in ZP2 environment, $54 \mathrm{~kg} \mathrm{ha}^{-1} \mathrm{~N}$ in $\mathrm{ZP} 1$ environment, and $51 \mathrm{~kg} \mathrm{ha}^{-1} \mathrm{~N}$ in RS1, ZP1 and RS2 environments. Integral protection against pests and weeds at all field locations was successfully accomplished by a proper use of adequate pesticides.

Analysis of technological quality traits. Protein content, wet gluten content, Zeleny sedimentation 
volume and deformation energy were determined by near infrared spectrometry (NIRS) with the analyser Infraneo (Chopin Technologies, France). The standard methods for calibration used in this study were as follows: protein content (EN ISO 16634-1:2006), wet gluten content (EN ISO 21415-2:2006), Zeleny sedimentation volume (EN ISO 5529:2006) and deformation energy (EN ISO 27971:2006). Quality tests for wet gluten content, Zeleny sedimentation volume and deformation energy were performed on intact grains of each genotype for each environment at $14 \%$ moisture level, whereas protein content was expressed on dry weight basis. Seeds were harvested at full maturity, the average moisture content after harvesting ranged from $12.2 \%$ to $12.8 \%$ in bread wheat and from $11.4 \%$ to $12.1 \%$ in durum wheat, consistently across genotypes of bread and durum wheat, respectively. NIRS represents rapid analysis for quality control and is widely used in the wheat processing industry for measuring moisture and protein contents, but also for detection of Zeleny sedimentation volume, mixograph dough parameters, extensigraph dough characteristics and alveograph dough properties (Surma et al., 2012).

Analysis of agronomic traits. Plots were handharvested at maturity, and grain yield (YLD) was determined per elementary plot and expressed as $\mathrm{kg} \mathrm{ha}^{-1}$. Plant height $(\mathrm{PH})$, number of grains per spike (GNS) and spike length (SL) were measured on 20 representative plants per elementary plot per replication. Thousand grain weight (TGW) was assessed from the harvested grain as three samples of 1000 grains per elementary plot per replication. The grain length $(\mathrm{GL})$, grain width $(\mathrm{GW})$ and grain thickness (GT) were measured by a digital electronic micrometre from the samples of twenty grains per elementary plot per replication. According to Tukey (HSD) test, the number of different homogenic sub-groups for grain thickness was 8 and 7 in bread and durum wheat, respectively. The productive tillering coefficient (PTC) was determined as a ratio of the number of spikes in the stage of maturation and the number of overwintered plants determined in the spring at the elementary plot per each replication. Grain vitreousness $(\mathrm{GV})$ was determined by the method given in Kaluđerski and Filipović (1998) with a farinator, allowing 50 wheat grains to be held firmly while a blade cuts them transversely. The percentage of vitreous grains was calculated by examining the crosssection of the grains and by obtaining the mean value of the 50 grains $\times 2$ following the formula:

Grain vitreousness $(\%)=\mathrm{A}+\frac{3}{4} \mathrm{~B}+\frac{1}{2} \mathrm{C}+\frac{1}{4} \mathrm{D}$,

were $\mathrm{A}$ is number of fully vitreous grains, $\mathrm{B}-$ number of vitreous grains with more than $75 \%$ of grain cross-section being vitreous, $\mathrm{C}$ - number of vitreous grains with $50 \%$ to $75 \%$ grain cross-section being vitreous, $\mathrm{D}$ - number of vitreous grains with $25 \%$ to $50 \%$ grain cross-section being vitreous.

Statistical analysis. The two-way analysis of variance $(A N O V A)$ based on random complete block design, with the fixed effects of genotype and environment, served for the quantification of the mean squares of the sources of variation, which were used for the calculation of the components of variance according to Falconer and Mackay (1996). Environment represented vegetation season $\times$ location combination. Multivariate analysis of variance (MANOVA) was performed as tests of betweensubjects effects. Testing the statistical significance of the difference in trait means between bread wheat and durum wheat was carried out using $t$-test, whereas Tukey (HSD) test designated statistical significance of the difference in trait means between genotypes of bread wheat for each trait and independently, between genotypes of durum wheat for each trait. Broad sense heritability $\left(h_{b}^{2}\right)$ was calculated as the ratio the genotypic variance to the phenotypic variance, and expected genetic advance as part of the mean for each trait at 5\% selection intensity $(k=2.056)$ was evaluated as in Falconer and Mackay (1996). In order to compare the extent of predicted genetic advance of different traits with different measurement units, expected genetic advance as percent of mean (\%) was computed. The genotype-by-trait $(\mathrm{G} \times \mathrm{T})$ biplot was used to visualise associations of agronomic traits, technological quality properties, and also profiles of genotypes by traits. The ANOVA, Tukey (HSD) test, MANOVA and $\mathrm{G} \times \mathrm{T}$ analysis were done within the computing environment $R$ ( $R$ Development Core Team, 2013).

\section{Results and discussion}

Variability of the examined technological quality traits and descriptive statistical parameters are given in Table 1 .

The protein content varied from $12.4 \%$ to $15.4 \%$ in bread wheat, and from $14.3 \%$ to $17.1 \%$ in durum wheat (Table 1). According to our results, a similar range for protein content of 10.5-16.3\% was reported by Yang et al. (2014) for 330 Chinese bread wheat cultivars, whereas larger variation of $8.3-17.6 \%$ for 162 bread wheat cultivars from European Wheat Catalogue was shown by Branlard et al. (2001). Mean value for protein content of bread wheat (13.8\%) was higher than in Polish and German $(12.5 \%)$ and American $(12.7 \%)$ cultivars of winter wheat (Table 1) (Fufa et al., 2005; Rozbicki et al., 2015 ), but similar to $14.5 \%$ of the bread wheat from the worldwide collection (Bordes et al., 2008). Lower values than ours for protein content mean value of durum wheat were from $12-13.9 \%$ as shown by other authors (Bilgin et al., 2010; Žilić et al., 2010). The homogenic groups of 10 and 11 were observed for protein content, according to Tukey (HSD) test, in bread and durum wheat, respectively. The wet gluten content ranged from $22.8 \%$ to $30.3 \%$ for bread wheat genotypes, and from $28.9 \%$ to $36.3 \%$ for durum wheat genotypes (Table 1 ), which is smaller range of variation compared to variation of $24-40.5 \%$ and $14-48 \%$ for wet gluten content reported in bread wheat and in durum wheat by Bilgin et al. (2010) and Yang et al. (2014), respectively. Žilić et al. (2010) documented 1.6-fold higher wet gluten content in durum wheat than in bread wheat, which is slightly higher than analogous value from our study of 1.3. The Tukey (HSD) test determined 9 and 7 homogenic subgroups for wet gluten content in bread and durum wheat, respectively. The gliadins are responsible for the viscous properties of dough during mixing, whereas glutenins as polymeric proteins reduce dough extensibility and increase dough strength (Różyło, Laskowski, 2011). The Zeleny sedimentation volume was from 39.4 to $67.1 \mathrm{~mL}$ in bread wheat genotypes and from 37.4 to $48.3 \mathrm{~mL}$ in durum wheat genotypes (Table 1), which is a higher and wider range in comparison to results of Kaya and Akçura (2014) for bread wheat, and of Szumiło et al. (2010) 
Table 1. Protein content, wet gluten content, Zeleny sedimentation volume and deformation energy of bread and durum wheat genotypes represented as mean values across six environments

\begin{tabular}{|c|c|c|c|c|c|}
\hline Genotype & Code & $\begin{array}{c}\text { Protein } \\
\text { content } \\
\% \\
\end{array}$ & $\begin{array}{c}\text { Wet gluten } \\
\text { content } \\
\% \\
\end{array}$ & $\begin{array}{c}\text { Zeleny sedimentation } \\
\text { volume } \\
\mathrm{mL}\end{array}$ & $\begin{array}{c}\text { Deformation } \\
\text { energy } \\
10^{-4} \mathrm{~J} \\
\end{array}$ \\
\hline \multicolumn{6}{|c|}{ Triticum aestivum L. ssp. aestivum (bread wheat) } \\
\hline Žitarka & $\mathrm{P} 1$ & $15.1 \mathrm{i}$ & $30.3 \mathrm{i}$ & $64.2 \mathrm{j}$ & $333.8 \mathrm{j}$ \\
\hline Stephens & $\mathrm{P} 2$ & $13.5 \mathrm{de}$ & $26.2 \mathrm{ef}$ & $43.0 \mathrm{~b}$ & $205.0 \mathrm{~b}$ \\
\hline Renan & $\mathrm{P} 3$ & $15.1 \mathrm{i}$ & 29.2 ghi & $67.1 \mathrm{k}$ & $313.2 \mathrm{i}$ \\
\hline Caldwell & P4 & $12.5 \mathrm{a}$ & $23.1 \mathrm{ab}$ & $46.1 \mathrm{~d}$ & $219.2 \mathrm{c}$ \\
\hline Abe & P5 & $14.3 \mathrm{gh}$ & $28.9 \mathrm{~g}$ & $48.3 \mathrm{e}$ & $242.6 \mathrm{e}$ \\
\hline Auburn & P6 & $14.1 \mathrm{fg}$ & $26.4 \mathrm{ef}$ & $44.5 \mathrm{c}$ & $259.4 \mathrm{f}$ \\
\hline Frankenmuth & P7 & $13.0 \mathrm{~b}$ & $25.8 \mathrm{def}$ & $39.4 \mathrm{a}$ & $179.3 \mathrm{a}$ \\
\hline Apache & P8 & $13.3 \mathrm{~cd}$ & $24.9 \mathrm{~cd}$ & $55.6 \mathrm{~h}$ & $246.1 \mathrm{e}$ \\
\hline ZP AU 12 & P9 & $13.1 \mathrm{bc}$ & $23.4 \mathrm{ab}$ & $55.6 \mathrm{~h}$ & $231.5 \mathrm{~d}$ \\
\hline Marija & $\mathrm{P} 10$ & $14.0 \mathrm{f}$ & $26.8 \mathrm{f}$ & $52.1 \mathrm{~g}$ & $279.8 \mathrm{~g}$ \\
\hline ZP 87/Ip & P11 & $12.4 \mathrm{a}$ & $22.8 \mathrm{a}$ & $59.4 \mathrm{i}$ & $241.4 \mathrm{e}$ \\
\hline Tecumseh & $\mathrm{P} 12$ & $15.4 \mathrm{j}$ & $30.1 \mathrm{hi}$ & $60.5 \mathrm{i}$ & $357.8 \mathrm{k}$ \\
\hline Pobeda & P13 & $14.5 \mathrm{~h}$ & $29.0 \mathrm{gh}$ & $64.9 \mathrm{j}$ & $294.6 \mathrm{~h}$ \\
\hline Zemunska rosa & P14 & $13.0 \mathrm{~b}$ & $24.3 \mathrm{bc}$ & $50.5 \mathrm{f}$ & $247.7 \mathrm{e}$ \\
\hline Ludwig & $\mathrm{P} 15$ & $13.7 \mathrm{e}$ & $25.5 \mathrm{de}$ & $52.6 \mathrm{~g}$ & $267.6 \mathrm{f}$ \\
\hline Mean & & $13.8 \mathrm{~A}$ & $26.5 \mathrm{~A}$ & $53.6 \mathrm{~A}$ & $261.2 \mathrm{~A}$ \\
\hline CV $(\%)$ & & 6.9 & 9.6 & 15.8 & 18.4 \\
\hline Min & & 12.4 & 22.8 & 39.4 & 179.3 \\
\hline Max & & 15.4 & 30.3 & 67.1 & 357.8 \\
\hline \multicolumn{6}{|c|}{ Triticum durum Desf. (durum wheat) } \\
\hline 37ED.7922 & D1 & $16.7 \mathrm{j}$ & 34.7 ef & $43.5 \mathrm{~cd}$ & $321.7 \mathrm{f}$ \\
\hline 37ED.7896 & D2 & $15.1 \mathrm{c}$ & $31.1 \mathrm{~b}$ & $37.9 \mathrm{a}$ & $295.7 \mathrm{bcd}$ \\
\hline 37ED.7817 & D3 & $16.0 \mathrm{~g}$ & $33.6 \mathrm{~cd}$ & $43.4 \mathrm{~cd}$ & $296.5 \mathrm{bcd}$ \\
\hline Varano & D4 & $16.8 \mathrm{j}$ & $35.2 \mathrm{ef}$ & $42.9 \mathrm{c}$ & $306.9 \mathrm{e}$ \\
\hline 37ED.7821 & D5 & $16.5 \mathrm{i}$ & $35.4 \mathrm{fg}$ & $48.3 \mathrm{~h}$ & $338.8 \mathrm{~g}$ \\
\hline 37ED.7880 & D6 & $16.3 \mathrm{~h}$ & $34.6 \mathrm{ef}$ & $41.4 \mathrm{~b}$ & $316.9 \mathrm{f}$ \\
\hline ZP 10/I & D7 & $15.5 \mathrm{de}$ & $31.1 \mathrm{~b}$ & $41.6 \mathrm{~b}$ & $303.0 \mathrm{de}$ \\
\hline SOD 55 & D8 & $14.9 \mathrm{~b}$ & $31.0 \mathrm{~b}$ & $47.9 \mathrm{gh}$ & $289.8 \mathrm{~b}$ \\
\hline 37ED./07 7803 & D9 & $15.5 \mathrm{~d}$ & $32.7 \mathrm{c}$ & $44.8 \mathrm{e}$ & $291.3 \mathrm{bc}$ \\
\hline DSP 66 & D10 & $16.6 \mathrm{ij}$ & $35.0 \mathrm{ef}$ & $43.1 \mathrm{c}$ & $354.6 \mathrm{~h}$ \\
\hline ZP 34/I & D11 & $15.6 \mathrm{e}$ & $33.1 \mathrm{c}$ & $42.4 \mathrm{bc}$ & $302.0 \mathrm{de}$ \\
\hline 37ED.7820 & D12 & $15.9 \mathrm{f}$ & $32.9 \mathrm{c}$ & $44.5 \mathrm{de}$ & $298.8 \mathrm{cde}$ \\
\hline 37ED./07 7857 & D13 & $17.1 \mathrm{k}$ & $36.3 \mathrm{~g}$ & $46.2 \mathrm{f}$ & $357.1 \mathrm{~h}$ \\
\hline 37ED./07 7849 & D14 & $16.0 \mathrm{fg}$ & $34.4 \mathrm{de}$ & $46.8 \mathrm{fg}$ & $318.0 \mathrm{f}$ \\
\hline ZP 120/I & D15 & $14.3 \mathrm{a}$ & $28.9 \mathrm{a}$ & $37.4 \mathrm{a}$ & $267.1 \mathrm{a}$ \\
\hline Mean & & $15.9 \mathrm{~B}$ & $33.3 \mathrm{~B}$ & $43.5 \mathrm{~B}$ & $310.6 \mathrm{~B}$ \\
\hline $\mathrm{CV}(\%)$ & & 4.9 & 6.2 & 7.3 & 7.9 \\
\hline Min & & 14.3 & 28.9 & 37.4 & 267.1 \\
\hline Max & & 17.1 & 36.3 & 48.3 & 357.1 \\
\hline
\end{tabular}

Note. Mean values in each column labelled with the same lowercase letter are not significantly different $(p<0.05)$ based on the Tukey (HSD) test; means in each column labelled with the same uppercase letter are not significantly different between wheat species according to the $t$-test $(p<0.05)$; CV - coefficient of variation.

for durum wheat. Sedimentation values evaluated as $<15 \mathrm{~mL}$ represent weak, 16-24 mL medium, 25-36 mL strong and over 36 very strong gluten (Basçiftçi, Kınacı, 2015), inferring strong gluten quality in all durum wheat genotypes and 10 bread wheat genotypes in our study. The mean value for Zeleny sedimentation volume $(53.6 \mathrm{~mL})$ in bread wheat in our study was higher than the mean value of $30.7 \mathrm{~mL}$ of hard red winter wheat from Nebraska (Fufa et al., 2005), of $30.3 \mathrm{~mL}$ of Chinese bread wheat cultivars (Yang et al., 2014) and of $28.6 \mathrm{~mL}$ of 162 bread wheat cultivars from European Wheat Catalogue (Branlard et al., 2001), but similar to the value of $52.8 \mathrm{~mL}$ reported by Zanetti et al. (2001). According to Tukey (HSD) test, the number of homogenic subgroups for Zeleny sedimentation volume was different in bread and durum wheat -11 and 8 , respectively. The deformation energy ranged from 179.3 to $357.810^{-4} \mathrm{~J}$ for bread wheat genotypes, and from 267.1 to $357.110^{-4} \mathrm{~J}$ for durum wheat genotypes (Table 1), whereas the wider range of variation for bread wheat of 208-573 $10^{-4} \mathrm{~J}$ was obtained by Maghirang et al. (2006), and smaller ranges of 209.2-287.6 $10^{-4} \mathrm{~J}$ and of 64.3-187.6 $10^{-4} \mathrm{~J}$ were reported in bread wheat by Surma et al. (2012) and in durum wheat by Abinasa et al. (2012), respectively. The number of homogenic sub-groups for deformation energy was 11 and 8 , in bread and durum wheat, respectively, based on Tukey (HSD) test. It is interesting to notice that the same top three genotypes of bread wheat with the highest values for protein content, wet gluten content and deformation energy were 'Tecumseh' from USA, 'Žitarka' from Croatia and 'Renan' from France, corroborating the correlations between these quality traits. In regard to 
Zeleny sedimentation volume, the promising genotypes of bread wheat with the highest mean values were 'Žitarka' and 'Pobeda' from Croatia and Serbia, respectively, representing genetic material bred in Balkan's agroecological region. Durum wheat lines from CIMMYT $37^{\text {th }}$ Elite Durum Unreplicated Yield Trial (37ED./07 7857, 37ED.7922 and 37ED.7821) and Italian cultivar 'Varano' proved to be superior genotypes regarding the highest values observed for protein content and wet gluten content, whereas the same CIMMYT 37EDUYT lines (37ED./07 7857 and 37ED.7821) as previously, another two lines (37ED./07 7849 and Slovakian cultivar SOD 55) were the best for Zeleny sedimentation volume. The same two CIMMYT 37EDUYT lines (37ED.7857 and 37ED./07 7821) as previously and the line DSP-
MD-01 No. 66 from ICARDA DSP-MD-01-Durum Segregating Populations-Mediterranean Dryland (season 2000-2001) were the most promising for quality regarding high deformation energy. According to the $t$-test, significant differences were observed between means of all examined technological quality traits, with the values of protein content, wet gluten content and deformation energy being higher in durum wheat, and with the values of Zeleny sedimentation volume being higher in bread wheat (Table 1).

MANOVA was presented as multiple tests of between-subjects effects for bread and durum wheat, separately, showing statistical significance $(p<0.001)$ of all sources of variation (Table 2).

Table 2. Multivariate analysis of variance $(M A N O V A)$ for technological quality traits of bread and durum wheat

\begin{tabular}{|c|c|c|c|c|c|c|c|}
\hline \multirow{2}{*}{ Source of variation } & \multirow{2}{*}{$\begin{array}{l}\text { Dependent } \\
\text { variable }\end{array}$} & $F$ & $p$ & Partial $\eta^{2}$ & $F$ & $p$ & Partial $\eta^{2}$ \\
\hline & & \multicolumn{3}{|c|}{ bread wheat } & \multicolumn{3}{|c|}{ durum wheat } \\
\hline \multirow{4}{*}{ Location (L) } & $\mathrm{PC}$ & 3313.5 & 0.000 & 0.961 & 935.6 & 0.000 & 0.874 \\
\hline & WG & 1104.2 & 0.000 & 0.891 & 232.1 & 0.000 & 0.632 \\
\hline & $\mathrm{ZS}$ & 4311.4 & 0.000 & 0.970 & 790.8 & 0.000 & 0.854 \\
\hline & $\mathrm{W}$ & 1559.0 & 0.000 & 0.920 & 401.4 & 0.000 & 0.748 \\
\hline \multirow{4}{*}{ Season (S) } & $\mathrm{PC}$ & 7506.3 & 0.000 & 0.965 & 29940.9 & 0.000 & 0.991 \\
\hline & WG & 2218.7 & 0.000 & 0.892 & 7305.7 & 0.000 & 0.964 \\
\hline & $\mathrm{ZS}$ & 756.2 & 0.000 & 0.737 & 8375.7 & 0.000 & 0.969 \\
\hline & $\mathrm{W}$ & 3762.7 & 0.000 & 0.933 & 12120.6 & 0.000 & 0.978 \\
\hline \multirow{4}{*}{ Genotype (G) } & $\mathrm{PC}$ & 476.9 & 0.000 & 0.961 & 573.0 & 0.000 & 0.967 \\
\hline & WG & 106.5 & 0.000 & 0.847 & 103.8 & 0.000 & 0.843 \\
\hline & $\mathrm{ZS}$ & 984.8 & 0.000 & 0.981 & 186.1 & 0.000 & 0.906 \\
\hline & $\mathrm{W}$ & 589.3 & 0.000 & 0.968 & 197.4 & 0.000 & 0.911 \\
\hline \multirow{4}{*}{$\mathrm{L} \times \mathrm{S}$} & $\mathrm{PC}$ & 1107.0 & 0.000 & 0.891 & 5351.3 & 0.000 & 0.975 \\
\hline & WG & 311.5 & 0.000 & 0.698 & 1613.6 & 0.000 & 0.923 \\
\hline & $\mathrm{ZS}$ & 219.4 & 0.000 & 0.619 & 105.2 & 0.000 & 0.438 \\
\hline & $\mathrm{W}$ & 531.6 & 0.000 & 0.797 & 4007.3 & 0.000 & 0.967 \\
\hline \multirow{4}{*}{$\mathrm{G} \times \mathrm{L}$} & $\mathrm{PC}$ & 20.1 & 0.000 & 0.676 & 145.1 & 0.000 & 0.938 \\
\hline & WG & 3.8 & 0.000 & 0.283 & 33.9 & 0.000 & 0.778 \\
\hline & ZS & 170.8 & 0.000 & 0.947 & 58.2 & 0.000 & 0.858 \\
\hline & $\mathrm{W}$ & 18.2 & 0.000 & 0.654 & 63.3 & 0.000 & 0.868 \\
\hline \multirow{4}{*}{$\mathrm{G} \times \mathrm{S}$} & $\mathrm{PC}$ & 40.6 & 0.000 & 0.678 & 121.4 & 0.000 & 0.863 \\
\hline & WG & 15.0 & 0.000 & 0.437 & 19.4 & 0.000 & 0.501 \\
\hline & $\mathrm{ZS}$ & 126.7 & 0.000 & 0.868 & 59.7 & 0.000 & 0.756 \\
\hline & W & 32.2 & 0.000 & 0.625 & 26.4 & 0.000 & 0.578 \\
\hline \multirow{4}{*}{$\mathrm{L} \times \mathrm{S} \times \mathrm{G}$} & $\mathrm{PC}$ & 20.3 & 0.000 & 0.678 & 70.7 & 0.000 & 0.880 \\
\hline & WG & 5.6 & 0.000 & 0.368 & 9.2 & 0.000 & 0.487 \\
\hline & $\mathrm{ZS}$ & 105.8 & 0.000 & 0.916 & 32.8 & 0.000 & 0.773 \\
\hline & $\mathrm{W}$ & 28.1 & 0.000 & 0.745 & 18.0 & 0.000 & 0.652 \\
\hline
\end{tabular}

$\mathrm{PC}$ - protein content, WG - wet gluten content, ZS - Zeleny sedimentation volume, $\mathrm{W}$ - deformation energy

The hierarchy of importance of sources of variation for the examined quality traits according to partial $\eta^{2}$ from MANOVA were: $\mathrm{S}>\mathrm{L}=\mathrm{G}>\mathrm{L} \times \mathrm{S}>\mathrm{G}$ $\times \mathrm{S}=\mathrm{L} \times \mathrm{S} \times \mathrm{G}>\mathrm{G} \times \mathrm{L}($ PC-bread wheat) and $\mathrm{S}>\mathrm{L}$ $\times \mathrm{S}>\mathrm{G}>\mathrm{G} \times \mathrm{L}>\mathrm{L} \times \mathrm{S} \times \mathrm{G}>\mathrm{L}>\mathrm{G} \times \mathrm{S}$ (PC-durum wheat); $\mathrm{S}>\mathrm{L}>\mathrm{G}>\mathrm{L} \times \mathrm{S}>\mathrm{G} \times \mathrm{S}>\mathrm{L} \times \mathrm{S} \times \mathrm{G}>\mathrm{G} \times$ $\mathrm{L}$ (WG-bread wheat) and $\mathrm{S}>\mathrm{L} \times \mathrm{S}>\mathrm{G}>\mathrm{G} \times \mathrm{L}>\mathrm{L}>$ $\mathrm{G} \times \mathrm{S}>\mathrm{L} \times \mathrm{S} \times \mathrm{G}$ (WG-durum wheat); $\mathrm{G}>\mathrm{L}>\mathrm{G} \times \mathrm{L}$ $>\mathrm{L} \times \mathrm{S} \times \mathrm{G}>\mathrm{G} \times \mathrm{S}>\mathrm{S}>\mathrm{L} \times \mathrm{S}$ (ZS-bread wheat) and $\mathrm{S}>\mathrm{G}>\mathrm{G} \times \mathrm{L}>\mathrm{L}>\mathrm{L} \times \mathrm{S} \times \mathrm{G}>\mathrm{G} \times \mathrm{S}>\mathrm{L} \times \mathrm{S}(\mathrm{ZS}-$ durum wheat); $\mathrm{G}>\mathrm{S}>\mathrm{L}>\mathrm{L} \times \mathrm{S}>\mathrm{L} \times \mathrm{S} \times \mathrm{G}>\mathrm{G} \times \mathrm{L}$ $>\mathrm{G} \times \mathrm{S}$ (W-bread wheat) and $\mathrm{S}>\mathrm{L} \times \mathrm{S}>\mathrm{G}>\mathrm{G} \times \mathrm{L}$ $>\mathrm{L}>\mathrm{L} \times \mathrm{S} \times \mathrm{G}>\mathrm{G} \times \mathrm{S}$ (W-durum wheat) (Table 2 ).
The greater significance of environmental variation for Zeleny sedimentation volume and deformation energy in durum wheat, and for protein content and wet gluten content in bread and durum wheat, in this study, is compliant with the results of Drezner et al. (2007) and Bilgin et al. (2010), stating strong environmental impact on bread and durum wheat quality traits-protein content, wet gluten content and deformation energy. Rozbicki et al. (2015) pointed out that the genotype as source of variation was more important than ecological factors on gluten quality coupled to Zeleny sedimentation for bread wheat, similarly as shown in this study. Hristov and Mladenov (2005) also showed for 20 cultivars of bread 
wheat statistical significance $(p<0.01)$ of all interaction effects $(\mathrm{G} \times \mathrm{L}, \mathrm{G} \times \mathrm{S}, \mathrm{L} \times \mathrm{S}$ and $\mathrm{L} \times \mathrm{S} \times \mathrm{G})$ on wet gluten content and Zeleny sedimentation volume variation, across five locations in Serbia.

Genetic parameters of wheat technological quality were under scrutiny of other authors (Bilgin et al., 2010; Tsegaye et al., 2012). The gluten quality and content are controlled by major genes, whereas protein content is determined by major genes and quantitative trait loci (QTLs) also. Larger genetic component of variance $\left(\sigma_{\mathrm{g}}^{2}\right)$ relative to the component of variance due to the genotype $\times$ environment interaction $\left(\sigma_{\text {ge }}^{2}\right)$ in this study was observed for the following technological quality traits in bread wheat: protein content (3.2 times higher), wet gluten content (2.9 times higher) and deformation energy (3.9 times higher) (Table 3).

Table 3. Variance components and genetic parameters of protein content, wet gluten content, Zeleny sedimentation volume and deformation energy in bread and durum wheat

\begin{tabular}{ccccccccccc}
\hline \multirow{2}{*}{ Trait } & Type & $\sigma_{\mathrm{g}}^{2}$ & $\sigma_{\mathrm{ge}}^{2}$ & $\sigma_{\mathrm{e}}^{2}$ & $\sigma_{\mathrm{p}}^{2}$ & $\begin{array}{c}\mathrm{h}_{\mathrm{b}}^{2} \\
\%\end{array}$ & $\begin{array}{c}\mathrm{CV}_{\mathrm{g}} \\
\%\end{array}$ & $\begin{array}{c}\mathrm{CV}_{\mathrm{ph}} \\
\%\end{array}$ & $\begin{array}{c}\mathrm{GA} \\
\text { GAM }\end{array}$ & $\begin{array}{c}\mathrm{GAM} \\
\%\end{array}$ \\
\hline \multirow{2}{*}{$\mathrm{PC}$} & bread wheat & 0.861 & 0.265 & 0.046 & 0.907 & 94.9 & 6.28 & 6.44 & 1.86 & 12.60 \\
& durum wheat & 0.486 & 0.691 & 0.116 & 0.602 & 80.7 & 4.12 & 4.58 & 1.29 & 7.62 \\
\hline \multirow{2}{*}{$\mathrm{WG}$} & bread wheat & 5.98 & 2.075 & 0.406 & 6.388 & 93.6 & 9.25 & 9.56 & 4.88 & 18.43 \\
& durum wheat & 3.41 & 4.967 & 0.869 & 4.279 & 79.7 & 5.54 & 6.21 & 3.40 & 10.19 \\
\hline \multirow{2}{*}{$\mathrm{ZS}$} & bread wheat & 61.96 & 59.124 & 9.93 & 71.88 & 86.2 & 14.69 & 15.82 & 15.05 & 28.09 \\
& durum wheat & 7.53 & 15.532 & 2.64 & 10.18 & 74.0 & 6.32 & 7.34 & 4.87 & 11.19 \\
\hline \multirow{2}{*}{$\mathrm{W}$} & bread wheat & 2213.92 & 564.494 & 98.01 & 2311.93 & 95.8 & 18.01 & 18.41 & 94.85 & 36.31 \\
& durum wheat & 490.92 & 679.848 & 116.38 & 607.30 & 80.8 & 7.13 & 7.94 & 41.04 & 13.21 \\
\hline
\end{tabular}

$\sigma_{\mathrm{g}}^{2}-$ genetic variance, $\sigma_{\mathrm{ge}}^{2}-$ variance of the genotype $\times$ environment interaction, $\sigma_{\mathrm{e}}^{2}-$ environmental variance, $\sigma_{\mathrm{p}}^{2}-$ phenotypic variance, $\mathrm{h}_{\mathrm{b}}^{2}$ - broad sense heritability, $\mathrm{CV}_{\mathrm{g}}$ - coefficient of genetic variation, $\mathrm{CV}_{\mathrm{ph}}-$ coefficient of phenotypic variation, $\mathrm{GA}$ - genetic advance, GAM - genetic advance as percent of mean; PC - protein content, WG - wet gluten content, ZS - Zeleny sedimentation volume, $\mathrm{W}$ - deformation energy

The relation $\frac{\sigma_{\mathrm{g}}^{2}}{\sigma_{\mathrm{ge}}^{2}}$ for Zeleny sedimentation volume content in bread wheat was equal to one. The larger $\sigma_{\mathrm{ge}}^{2}$ when compared to $\sigma_{\mathrm{g}}^{2}$ was determined for all technological quality traits in durum wheat: protein content (1.4 times higher), wet gluten content (1.5 times higher), Zeleny sedimentation volume (2.1 times higher) and deformation energy (1.4 times higher) (Table 3), which is in accordance with the findings of Bilgin et al. (2010) regarding $\frac{\sigma_{\mathrm{ge}}^{2}}{\sigma_{\mathrm{g}}^{2}}$ relation of 2 and 2.4 for protein content and wet gluten content, respectively. Durum wheat genotypes exhibited generally larger influence of genotype $\times$ environment interaction on technological quality traits compared to bread wheat. The existence of large genotype $\times$ environment interaction indicates the necessity of carrying out the selection in a range of environments and breeding different genotypes adaptable for specific environments (Falconer, Mackay, 1996). The environmental component of variance $\left(\sigma_{\mathrm{g}}^{2}\right)$ was smaller than $\sigma_{\mathrm{g}}^{2}$ and $\sigma_{\mathrm{ge}}^{2}$ for all the traits, both in bread and durum wheat.

Heritability in a broad sense $\left(\mathrm{h}_{\mathrm{b}}^{2}\right)$ was very high $(>90 \%)$ for protein content, wet gluten content and deformation energy in bread wheat (Table 3). Higher hb 2 values $(>95 \%)$ than ours for protein content in Triticum aestivum recombinant inbred lines (RILs) and improved lines, were reported by Zanetti et al. (2001) and Basçiftçi and Kinac1 (2015). The probable explanation for such high $h_{b}^{2}$ values is the genetic control of the phenotypic expression for protein content with several genes with major and/or minor effects. Šarčević et al. (2014) obtained very high $(>94 \%)$ values for $h_{b}^{2}$ for protein content, wet gluten content and Zeleny sedimentation volume for 19 winter wheat cultivars under both high and low N fertilization level, whereas Aydin et al. (2010) showed $\mathrm{h}_{\mathrm{b}}^{2}$ for protein content and Zeleny sedimentation volume to be $87.4 \%$ and $89.1 \%$ for 25 genotypes of bread wheat, respectively. Conversely, Kaya and Akcura (2014) reported small to medium values for $\mathrm{h}_{\mathrm{b}}^{2}$ for protein content, wet gluten content and Zeleny sedimentation volume of $45 \%, 41 \%$ and $52 \%$, respectively, for 20 genotypes of bread wheat. High $\mathrm{h}_{\mathrm{b}}^{2}(80-90 \%)$ was showed for protein content and deformation energy in durum wheat and for Zeleny sedimentation volume in bread wheat (Table 3), differently from small to medium values $\mathrm{h}_{\mathrm{b}}^{2}$ for Zeleny sedimentation volume of $67 \%$, obtained for 162 cultivars of bread wheat according to Branlard et al. (2001), and to $45 \%$ for protein content in most widely grown Turkish durum wheat cultivars, according to Kaya and Akcura (2014). Broad sense heritability was moderately high (70-80\%) for wet gluten content and Zeleny sedimentation volume in durum wheat (Table 3), whereas Kaya and Akcura (2014) reported lower value for Zeleny sedimentation volume.

The highest values of the coefficient of genetic variation $\left(\mathrm{CV}_{\mathrm{g}}\right)$ and coefficient of phenotypic variation $\left(\mathrm{CV}_{\mathrm{ph}}\right)$ were recorded for deformation energy (18.01\% and $18.41 \%$, respectively) in bread wheat (Table 3 ). The minimum values of $\mathrm{CV}_{\mathrm{g}}$ and $\mathrm{CV}_{\mathrm{ph}}$ of $4.12 \%$ and $4.58 \%$, respectively, were shown for protein content in durum wheat, quite smaller than $\mathrm{CV}_{\mathrm{ph}}$ of $18.37 \%$ reported by Bilgin et al. (2010). $\mathrm{CV}_{\mathrm{g}}$ and $\mathrm{CV}_{\mathrm{ph}}$ were small $(<10 \%)$ for all examined traits except for Zeleny sedimentation volume and deformation energy in bread wheat, which showed medium variation $\left(10 \%<\mathrm{CV}_{\mathrm{ph}}<20 \%\right)$, in accordance with the findings of other authors (Fufa et al., 2005; Žilić et al., 2010; Yang et al., 2014). 
Heritability estimate is insufficient to make significant improvement through selection unless accompanied by favourable amount of genetic advance (Bilgin et al., 2010). Non-additive gene effects relate to high heritability but low genetic advance of a trait of interest, whereas additive gene action stipulates high, both, heritability and genetic advance, leading to the success of selection (Laghari et al., 2010). Very high and high $\mathrm{h}_{\mathrm{b}}^{2}$ estimate of $95.8 \%$ and $86.2 \%$ coupled with high expected genetic advance $(>20 \%)$ were shown for deformation energy and Zeleny sedimentation volume in bread wheat, respectively, whereas very high $\mathrm{h}_{\mathrm{b}}^{2}$ estimate $(>93 \%)$ and moderate expected genetic advance of $12.6 \%$ and $18.4 \%$ were observed for protein content and wet gluten content in bread wheat, respectively (Table 3). Basçiftçi and Kınacı (2015) obtained higher genetic advance for Zeleny sedimentation volume in bread wheat lines of $30.1 \%$. The smallest genetic advance value $(7.6 \%)$ was determined for protein content in durum wheat. Contrary to our results, Bilgin et al. (2010) showed both small $\mathrm{h}_{\mathrm{b}}^{2}$ $(<40 \%)$ and genetic advance $(<9 \%)$ values for protein content and wet gluten content in 25 genotypes of durum wheat, similarly to $51 \%$ and $4.9 \%$, respectively, for protein content in 23 durum wheat genotypes reported by Tsegaye et al. (2012).

Genotype-by-trait analyses of interrelationship between agronomic characteristics and technological quality properties calculated from multi-environment trial data for bread and durum wheat are shown (Figs 1-2). Across the 15 tested bread wheat genotypes grain yield was positively associated with Zeleny sedimentation volume, but negatively with the other three technological quality properties - protein content, wet gluten content and deformation energy (Fig. 1). These relations suggest that it is difficult to combine higher grain yield, protein content, wet gluten content and deformation energy in a single genotype. Similarly, Kaya and Akcura (2014) showed negative correlation between grain yield and protein content, and grain yield and wet gluten content in twenty genotypes of bread wheat. The positive associations were found for grain thickness and Zeleny sedimentation volume and to lesser extent between grain thickness and protein content, grain thickness and wet gluten content, grain thickness and deformation energy, making grain thickness suitable agronomic trait that can be indirect selection criterion. Varga et al. (2003) found positive correlation between grain thickness and wet gluten content for winter wheat genotypes, whereas Drikvand et al. (2013) showed positive correlation between grain width and protein content for 92 bread wheat cultivars and breeding lines. All four investigated parameters of technological quality were negatively associated with grain number per spike and spike length. Bread wheat genotypes 'Žitarka' and 'Renan' had the highest values for protein content, wet gluten content, Zeleny sedimentation volume and deformation energy, with 'Renan' being superior in regard to grain yield and thousand grain weight. If it is desirable to further improve grain yield of 'Žitarka', cross ZP AU $12 \times$ 'Žitarka' may be useful.

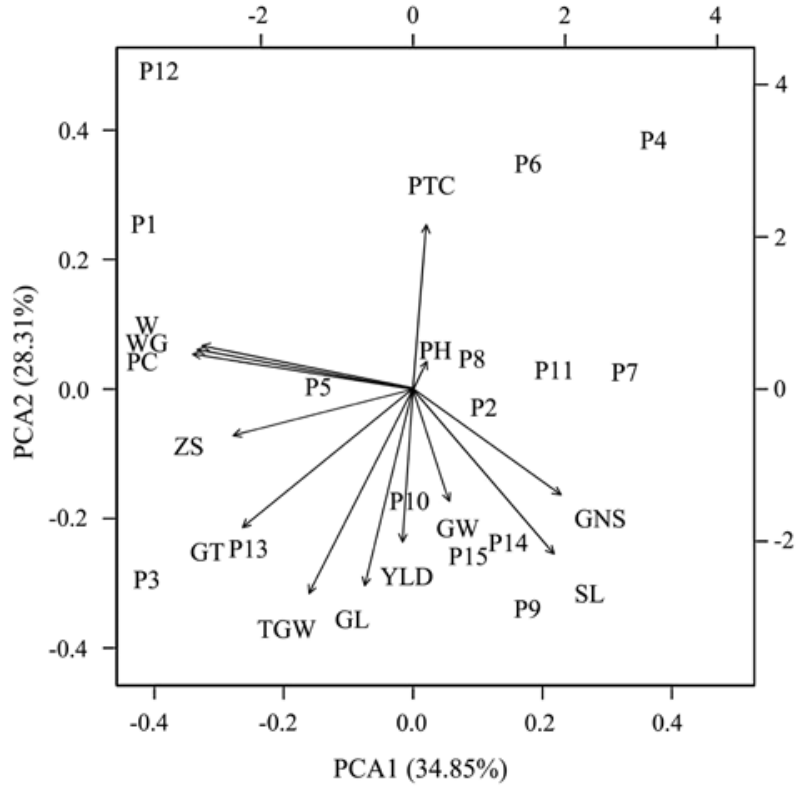

YLD - grain yield, TGW - thousand grain weight, $\mathrm{PH}$ - plant height, SL - spike length, GNS - grain number per spike, GL - grain length, GW - grain width, GT - grain thickness, PTC - productive tillering coefficient; PC - protein content, WG wet gluten content, ZS - Zeleny sedimentation volume, W deformation energy

Figure 1. Genotype by trait $(\mathrm{G} \times \mathrm{T})$ biplot of 15 bread wheat genotypes (P1-P15) by nine agronomic and four technological quality characteristics measured across six environments

Across the 15 tested durum wheat genotypes grain yield was negatively correlated with protein content, wet gluten content, Zeleny sedimentation volume and deformation energy, suggesting impediment for combining higher grain yield, and four examined technological quality properties in a single genotype (Fig. 2). According to Bilgin et al. (2010), the negative correlation observed between protein content and grain yield resulted mainly from protein dilution by non-nitrogen compounds in the grain during grain filling. Grain thickness proved to be highly positively associated with Zeleny sedimentation volume and to a lesser extent to deformation energy, protein content and wet gluten content, respectively. Grain vitreousness was positively associated with protein content, and to lesser extent to wet gluten content, deformation energy and Zeleny sedimentation volume, which was also showed by El-Khayat et al. (2006) and Bilgin et al. (2010), as positive correlation of grain vitreousness and protein content and wet gluten content. Grain thickness and grain vitreousness can be indirect selection criteria for improving Zeleny sedimentation volume, protein content, deformation energy and wet gluten content in durum wheat. All four examined technological quality properties were negatively associated with the following agronomic characteristics: grain number per spike, spike length, plant height and productive tillering coefficient. The durum wheat genotypes 37ED./07 7857 and 37ED. 7880 had the highest protein content, wet gluten content, Zeleny sedimentation volume and deformation 


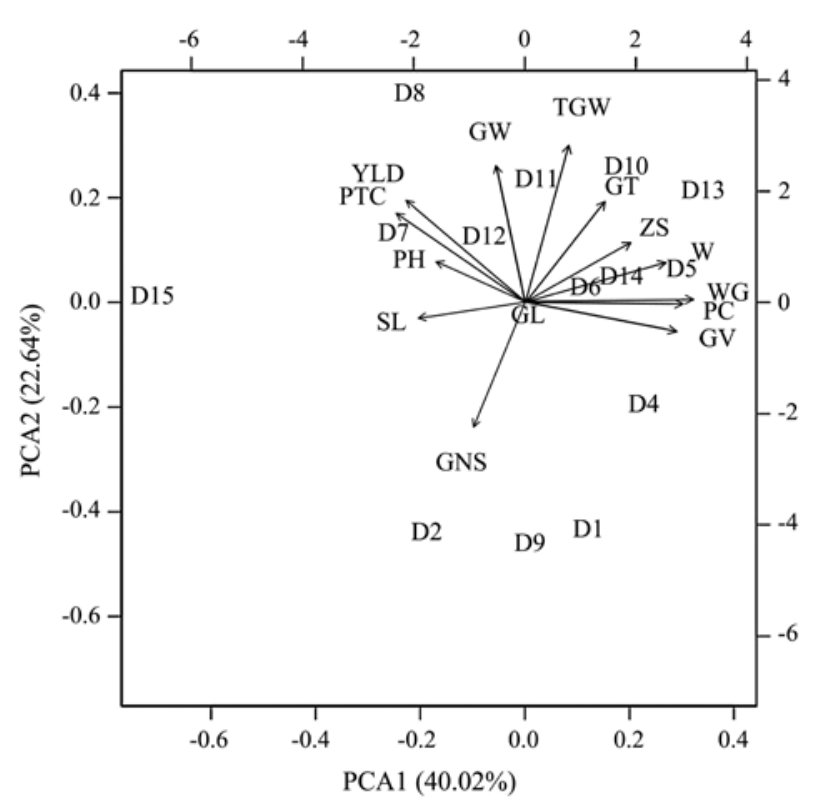

YLD - grain yield, TGW - thousand grain weight, $\mathrm{PH}$ - plant height, SL - spike length, GNS - grain number per spike, GL - grain length, GW - grain width, GT - grain thickness, GV - grain vitreousness, PTC - productive tillering coefficient; PC - protein content, WG - wet gluten content, ZS - Zeleny sedimentation volume, $\mathrm{W}$ - deformation energy

Figure 2. Genotype by trait $(\mathrm{G} \times \mathrm{T})$ biplot of 15 durum wheat genotypes (D1-D15) by ten agronomic and four technological quality characteristics measured across six environments

energy, with the first one being more superior in regard to the most of the investigated agronomic traits. If it is desirable to further improve grain yield level of 37ED./07 7857 and 37ED.7880, the cross with ZP 10/1 can be recommended.

\section{Conclusions}

1. Very high (95.8\%) and high (86.2\%) heritability in a broad sense $\left(\mathrm{h}_{\mathrm{b}}^{2}\right)$ for deformation energy and Zeleny sedimentation volume, respectively, in the studied genotypes of bread wheat, coupled with high expected genetic advance as percent of mean of $36.3 \%$ and $28.1 \%$, respectively, and predominant genetic variance $\left(\sigma_{\mathrm{g}}^{2}\right)$, the success from classical breeding approach can be anticipated for these two traits.

2. The moderately high heritability in a broad sense (74-80.8\%) was determined for grain protein content, wet gluten content, Zeleny sedimentation volume and deformation energy, accompanied by small genetic advance $(7.6 \%)$ for protein content and moderate genetic advance (10-13.2\%) for wet gluten content, Zeleny sedimentation volume and deformation energy, along with genotype $\times$ environment variance $\left(\sigma_{\text {ge }}^{2}\right)$ larger for about 1.4-2.1 to $\sigma_{\mathrm{g}}^{2}$, scored less success in breeding for protein content, wet gluten content, Zeleny sedimentation volume and deformation energy improvement in the studied genotypes of durum wheat.

3. The ratio of $\sigma_{\mathrm{g}}^{2}$ and $\left(\sigma_{\mathrm{g}}^{2} / \sigma_{\mathrm{ge}}^{2}\right)$ indicated greater stability for protein content, wet gluten content and deformation energy in the studied genotypes of bread wheat, and instability for all examined traits of technological quality in the studied genotypes of durum wheat.

4. Grain yield was positively correlated with Zeleny sedimentation volume, but negatively with protein content, wet gluten content and deformation energy, in the studied genotypes of bread wheat, whereas in the studied genotypes of durum wheat it showed negative correlations with all four technological quality properties. Taking into account strong positive association between grain thickness and Zeleny sedimentation volume, and to a lesser extent between grain thickness and protein content, grain thickness and wet gluten content, grain thickness and deformation energy, grain thickness can be a suitable agronomic trait that can serve as indirect selection criterion in the studied genotypes of bread wheat and durum wheat improvement of examined technological quality properties. Grain vitreousness was positively correlated with protein content and to a lesser extent to wet gluten content, deformation energy and Zeleny sedimentation volume and can be also considered as the attribute of indirect selection for these technological quality traits in the studied genotypes of durum wheat.

\section{Acknowledgements}

The special gratitude goes to the Institute of Field and Vegetable Crops for providing part of the seed materials, field site and technical assistances. Authors acknowledge the financial support by the Ministry of Education, Science and Technological Development of the Republic of Serbia within the Project TR 31092.

Received 05052017 Accepted 04092017

\section{References}

1. Abinasa M., Bultosa G., Ayana A. 2012. Variation and associations of quality parameters in Ethiopian durum wheat (Triticum turgidum L. var. durum) genotypes. International Journal of Plant Breeding and Genetics, 6 (1): 17-31. https://doi.org/10.3923/ijpbg.2012.17.31

2. Aydin N., Sermet C., Mut Z., Bayramoglu H. O., Özcan H. 2010. Path analyses of yield and some agronomic and quality traits of bread wheat (Triticum aestivum L.) under different environments. African Journal of Biotechnology, 9 (32): 5131-5134.

3. Basçiftçi Z. B., Kınacı G. 2015. Investigation on quality characters and correlations among hardness with others in bread wheat. GIDA - Journal of Food, 40 (4): 187-192.

4. Bilgin O., Korkut K. Z., Baser I., Daglioglu O., Ozturk I., Kahraman T., Balkan A. 2010. Variation and heritability for some semolina characteristics and grain yield relations in durum wheat (Triticum durum Desf). World Journal of Agricultural Sciences, 6 (3): 301-308.

5. Bordes L., Branlard G., Qury F. X., Charmet G., Balfourier F. 2008. Agronomic characteristic, grain quality and flour rheology of 372 bread wheat in a worldwide core collection. Journal of Cereal Science, 48: 569-579. https://doi.org/10.1016/j.jcs.2008.05.005

6. Branlard G., Dardevet M., Saccomano R., Lagoutte F., Gourdon J. 2001. Genetic diversity of wheat storage proteins and bread wheat quality. Euphytica, 119: 59-67. https://doi.org/10.1023/A:1017586220359 
7. Carver B. F. 2009. Wheat science and trade ( $1^{\text {st }}$ ed.). https://doi.org/10.1002/9780813818832

8. Deng Z., Zhao L., Liu B., Zhang K., Chen J., Qu H., Sun C., Zhang Y., Tian J. 2013. Conditional QTL mapping of sedimentation volume on seven quality traits in common wheat. Journal of Integrative Agriculture, 12 (12): 2125 2133. https://doi.org/10.1016/S2095-3119(13)60352-4

9. Drezner G., Dvojkovic K., Horvat D., Novoselovic D., Lalic A. 2007. Environmental impacts on wheat agronomic quality traits. Cereal Research Communications, 35 (2): 357-360. https://doi.org/10.1556/CRC.35.2007.2.48

10. Drikvand R., Bihamta M. R. Najafian G., Ebrahimi A. 2013. Kernel quality association and path analysis in bread wheat. International Journal of Biology, 5 (3): 73-79. https://doi.org/10.5539/ijb.v5n3p73

11. El-Khayat G. H., Samaan J., Manthey F. A., Fuller M. P., Brennan C. S. 2006. Durum wheat quality I: some physical and chemical characteristics of Syrian durum wheat genotypes. International Journal of Food Science and Technology, 41 (suppl. 2): 22-29. https://doi.org/10.1111/j.1365-2621.2006.01245.x

12. Falconer D. S., Mackay T. F. C. 1996. Introduction to quantitative genetics. Longman ( $5^{\text {th }}$ ed. $)$.

13. Fufa H., Baenziger P. S., Beecher B. S., Graybosch R. A., Eskridge K. M., Nelson, L. A. 2005. Genetic improvement trends in agronomic performances and end-use quality characteristics among hard red winter wheat cultivars in Nebraska. Euphytica, 144: 187-198. https://doi.org/10.1007/s10681-005-5811-x

14. Gaines C. S., Fregeau Reid J., Vander Kant C., Morris C. F. 2006. Comparison of methods for gluten strength assessment. Cereal Chemistry, 83 (3): 284-286. https://doi.org/10.1094/CC-83-0284

15. Hristov N., Mladenov N. 2005. Indicators of wheat technological quality in time and space. Bulletin of the Field and Vegetable Crops Institute Novi Sad, 41: 221-234.

16. Kaluđerski G., Filipović N. 1998. Methods of analysis of cereal grain, flour and end-use products quality ( $1^{\text {st }} \mathrm{ed}$.) (in Serbian).

17. Kaya Y., Akcura M. 2014. Effects of genotype and environment on grain yield and quality traits in bread wheat (T. aestivum L.). Food Science and Technology (Campinas), 34 (2): 386-393. https://doi.org/10.1590/fst.2014.0041

18. Laghari K. A., Sial M. A., Arain M. A., Mirbahar A. A., Pirzada A. J., Dahot M. U., Mangrio S. M. 2010. Heritability studies of yield and yield associated traits in bread wheat. Pakistan Journal of Botany, 42 (1): 111-115.

19. Maghirang E. B., Lookhart G. L., Bean S. R., Pierce R. O., Xie F., Caley M. S., Wilson J. D., Seabourn B. W., Ram M. S., Park S. H., Chung O. K., Dowell F. E. 2006. Comparison of quality characteristics and breadmaking functionality of hard red winter and hard red spring wheat. Cereal Chemistry, 83 (5): 520-528.

https://doi.org/10.1094/CC-83-0520

20. Monneveux P., Ruilian J., Satish C. M. 2012. Phenotyping for drought adaptation in wheat using physiological traits. Frontiers in Physiology, 2012 (3): 429. https://doi.org/10.3389/fphys.2012.00429

21. Royo C., Briceño-Félix G. A. 2011. Wheat breeding in Spain. Bonjean A. P. et al. (eds). The world wheat book. A history of wheat breeding, vol. 3, p. 121-154.

22. Rozbicki J., Ceglinska A., Gozdowski D., Jakubczak M., Cacak-Pietrzak G., Madry W., Golba J., Piechocinski M., Sobczynski G., Studnicki M., Drzazga T. 2015. Influence of the cultivar, environment and management on the grain yield and bread-making quality in winter wheat. Journal of Cereal Science, 61 (2015): 126-132. https://doi.org/10.1016/j.jcs.2014.11.001
23. Różyło R., Laskowski J. 2011. Predicting bread quality (bread loaf volume and crumb texture). Polish Journal of Food and Nutrition Sciences, 61 (1): 61-67. https://doi.org/10.2478/v10222-011-0006-8

24. Shewry P. R., Hey S. J. 2015. The contribution of wheat to human diet and health. Food and Energy Security, 4 (3): 178-202. https://doi.org/10.1002/fes3.64

25. Subira J., Peña R. J., Álvaro F., Ammar K., Ramdani A., Royo C. 2014. Breeding progress in the pasta-making quality of durum wheat cultivars released in Italy and Spain during the $20^{\text {th }}$ century. Crop and Pasture Science, 65: 16-26. https://doi.org/10.1071/CP13238

26. Surma M., Adamski T., Banaszak Z., Kaczmarek Z., Kuczynska A., Majcher M., Ługowska B., Obuchowski W., Salmanowicz B., Krystkowiak K. 2012. Effect of genotype, environment and their interaction on quality parameters of wheat breeding lines of diverse grain hardness. Plant Production Science, 15 (3): 192-203. https://doi.org/10.1626/pps.15.19

27. Szumiło G., Rachoń L., Stankowski S. 2010. The evaluation of grain and flour quality of spring durum wheat (Triticum durum Desf.). Polish Journal of Agronomy, 2: 78-82.

28. Šarčević H., Jukić K., Ikić I., Lovrić A. 2014. Estimation of quantitative genetic parameters for grain yield and quality in winter wheat under high and low nitrogen fertilization. Euphytica, 199: 57-67.

https://doi.org/10.1007/s10681-014-1154-9

29. Tsegaye D., Dessalegn T., Dessalegn Y., Share G. 2012. Genetic variability, correlation and path analysis in durum wheat germplasm (Triticum durum Desf). Agricultural Research Review, 1 (4): 107-112.

30. Varga B., Svečnjak Z., Jurković Z., Kovačević J., Jukić Ž. 2003. Wheat grain and flour quality as affected by cropping intensity. Food Technology and Biotechnology, 41 (4): 321-329.

31. Vizitiu D., Ognean M., Danciu I. 2012. Rheological evaluation of some laboratory mills. Bulletin of University of Agricultural Sciences and Veterinary Medicine ClujNapoca, 69 (2): 440-446.

32. Wieser H. 2007. Chemistry of gluten proteins. Food Microbiology, 24: 115-119. https://doi.org/10.1016/j.fm.2006.07.004

33. WRB 2014. A framework for international classification, correlation and communication ( $\left.2^{\text {nd }} \mathrm{ed}.\right)$. http://www.fao. org/3/a-i3794e.pdf

34. Yang X., Wua L., Zhua Z., Rena G., Liua S. 2014. Variation and trends in dough rheological properties and flour quality in 330 Chinese wheat varieties. The Crop Journal, 2: 195200. https://doi.org/10.1016/j.cj.2014.04.001

35. Zanetti S., Winzeler M., Feuillet C., Keller B., Messmer M. 2001. Genetic analysis of bread-making quality in wheat and spelt. Plant Breeding, 120: 13-19. https://doi.org/10.1046/j.1439-0523.2001.00552.x

36. Žilić S., Dodig D., Hadži-Tašković Šukalović V., Maksimović M., Saratlić G., Škrbić B. 2010. Bread and durum wheat compared for antioxidants contents, and lipoxygenase and peroxidase activities. International Journal of Food Science and Technology, 45: 1360-1367. https://doi.org/10.1111/j.1365-2621.2010.02251.x

37. Žilić S., Barać M., Pešić M., Dodig D., Ignjatović-Micić D. 2011. Characterization of proteins from grain of different bread and durum wheat genotypes. International Journal of Molecular Sciences, 12: 5878-5894. https://doi.org/10.3390/ijms12095878 
ISSN 1392-3196 / e-ISSN 2335-8947

Zemdirbyste-Agriculture, vol. 105, No. 1 (2018), p. 39-48

DOI $10.13080 / \mathrm{z}-\mathrm{a} .2018 .105 .006$

\title{
Triticum aestivum ir T. durum genetiniai parametrai kokybės technologinėms savybėms Serbijoje
}

\author{
G. Branković ${ }^{1}$, D. Dodig 2 , V. Pajić ${ }^{1}$, V. Kandić ${ }^{2}$, D. Knežević ${ }^{3}$, N. Đurić4 ${ }^{4}$ T. Živanović ${ }^{1}$ \\ ${ }^{1}$ Belgrado universitetas, Serbija \\ ${ }^{2}$ Kukurūzų tyrimų institutas "Zemun Polje", Serbija \\ ${ }^{3}$ Prištinos universitetas, Serbija \\ ${ }^{4} \mathrm{John}$ Naisbitt universitetas, Serbija
}

\section{Santrauka}

Baltymai yra svarbus kviečių maistinès vertès rodiklis; vienas jų - glitimas - lemia duoninių kviečių kepimo kokybę ir makaronų gamybai skirtų kviečių technologines savybes. Vertinant kviečių kokybès savybių genetinius parametrus galima nustatyti jų gerinimo galimybes. Augalinę medžiagą sudarè 30 pasaulyje paplitę duoninių ir kietujų kviečių genotipai. Bandymai buvo atlikti trijose Serbijos vietovėse du vegetacinius sezonus 2010-2011 ir 2011-2012 m. Baltymų kiekis, šlapio glitimo kiekis, sedimentacijos (Zeleny) tūris ir deformacijos energija buvo nustatyti naudojant artimosios srities infraraudonujų spindulių spektrometriją.

Siekiant nustatyti netiesioginès atrankos galimybe, tyrimo metu siekta ịvertinti: 1) kintamumą, variantiškumo komponentus, paveldimumą plačiąja prasme $\left(\mathrm{h}_{\mathrm{b}}^{2}\right)$, tikètiną genetinę pažangą baltymų kiekiui, šlapio glitimo kiekiui, Zeleny sedimentacijos tūriui ir deformacijos energijai; 2) ryšius tarp agronominių savybių ir baltymų kiekio, šlapio glitimo kiekio, Zeleny sedimentacijos verčių ir deformacijos energijos. Kietųjų kviečių didžiausi genetinès ir fenotipinès variacijos koeficientai $\left(\mathrm{CV}_{\mathrm{g}}\right.$ ir $\left.\mathrm{CV}_{\mathrm{ph}}\right)$ buvo nustatyti deformacijos energijos duoniniuose kviečiuose, atitinkamai 18 ir 18,4\%; mažiausios 4,1 ir 4,6\% vertès buvo nustatytos baltymų kiekio. Genetinio variantiškumo komponento $\left(\sigma_{\mathrm{g}}^{2}\right) /$ variantiškumo komponento ryšys dèl genotipo $\times$ aplinkos sąveikos $\left(\sigma_{\mathrm{ge}}^{2}\right)>1$ buvo nustatytas baltymų kiekio $(3,2)$, šlapio glitimo kiekio $(2,9)$ bei deformacijos energijos $(3,9)$ ir buvo lygus vienetui sedimentacijos vertėms duoniniuose kviečiuose. Kietuosiuose kviečiuose $\sigma_{\mathrm{ge}}^{2} / \sigma_{\mathrm{g}}^{2}>1$ buvo nustatytas baltymų kiekio $(1,4)$, šlapio glitimo kiekio $(1,5)$, Zeleny sedimentacijos tūrio $(2,1)$ ir deformacijos energijos $(1,4)$. Atsižvelgiant ị nustatytą labai aukštą ir aukštą deformacijos energijos ir Zeleny sedimentacijos tūrio $\mathrm{h}_{\mathrm{b}}^{2}$, atitinkamai 95,8 ir 86,2 \% duoniniuose kviečiuose kartu su didele genetine pažanga, atitinkamai 36,3 ir 28,1\%, galima tikètis klasikinès selekcijos sèkmès. Grūdų storis buvo labiau susijęs su sedimentacijos tūriu ir mažiau - su baltymų kiekiu, šlapio glitimo kiekiu ir deformacijos energija duoniniuose bei kietuosiuose kviečiuose ir kartu su stikliškumu kietuosiuose kviečiuose gali būti naudojami netiesioginei selekcinei atrankai.

Reikšminiai žodžiai: baltymai, glitimo stiprumas, paprastieji ir kietieji kviečiai, šlapias glitimas, tikètina genetine pažanga, sedimentacija. 